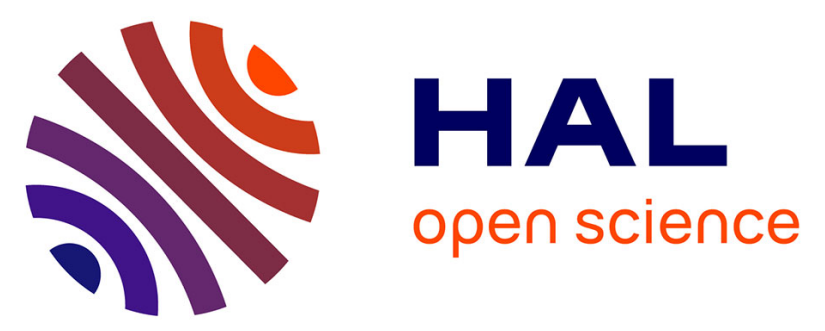

\title{
Dinuclear Copper(I) Complexes Combining Bis(diphenylphosphanyl)acetylene with 1,10-Phenanthroline Ligands
}

Jean-François Nierengarten, Iwona Nierengarten, Michel Holler, Alix Sournia-Saquet, Béatrice Delavaux-Nicot, Enrico Leoni, Filippo Monti, Nicola Armaroli

\section{To cite this version:}

Jean-François Nierengarten, Iwona Nierengarten, Michel Holler, Alix Sournia-Saquet, Béatrice Delavaux-Nicot, et al.. Dinuclear Copper(I) Complexes Combining Bis(diphenylphosphanyl)acetylene with 1,10-Phenanthroline Ligands. European Journal of Inorganic Chemistry, 2019, 2019 (22), pp.2665-2673. 10.1002/ejic.201900335 . hal-02335003

\section{HAL Id: hal-02335003 https://hal.science/hal-02335003}

Submitted on 26 Oct 2020

HAL is a multi-disciplinary open access archive for the deposit and dissemination of scientific research documents, whether they are published or not. The documents may come from teaching and research institutions in France or abroad, or from public or private research centers.
L'archive ouverte pluridisciplinaire HAL, est destinée au dépôt et à la diffusion de documents scientifiques de niveau recherche, publiés ou non, émanant des établissements d'enseignement et de recherche français ou étrangers, des laboratoires publics ou privés. 


\title{
Dinuclear Copper(I) Complexes Combining Bis(diphenylphosphino)acetylene with 1,10-Phenanthroline
} Ligands

\author{
Jean-François Nierengarten, ${ }^{\left[{ }^{[a]}\right]}$ Iwona Nierengarten, ${ }^{[a]}$ Michel Holler, ${ }^{[a]}$ Alix Sournia-Saquet, ${ }^{[b]}$ Béatrice \\ Delavaux-Nicot, ${ }^{*[\mathrm{~b}]}$ Enrico Leoni, ${ }^{[\mathrm{c}, \mathrm{d}]}$ Filippo Monti, ${ }^{[\mathrm{d}]}$ and Nicola Armaroli* ${ }^{*[\mathrm{~d}]}$
}

\begin{abstract}
Dinuclear copper(I) complexes have been prepared starting from bis(diphenylphosphino)acetylene (dppa), $\left[\mathrm{Cu}\left(\mathrm{CH}_{3} \mathrm{CN}\right)_{4}\right]\left(\mathrm{BF}_{4}\right)$ and various 1,10-phenanthroline ligands $(\mathrm{NN})$, namely 1,10-phenanthroline (phen), neocuproine (dmp), bathophenanthroline (Bphen), bathocuproine (Bdmp) and 2-phenyl1,10-phenanthroline $(\mathrm{mpp})$. The resulting $\left[\mathrm{Cu}_{2}(\mu \text {-dppa })_{2}(\mathrm{NN})_{2}\right]\left(\mathrm{BF}_{4}\right)_{2}$ complexes have been thus obtained in excellent yields ( 88 to $94 \%$ ). $X$-ray crystal structure analysis of four complexes revealed that the 10-membered dimetallacycle adopts a chair-like conformation in the solid state. Detailed variable temperature NMR investigations have evidenced dynamic coordination/decoordination of the NN ligands as well as ligand exchange reactions. At high temperature $\left(100^{\circ} \mathrm{C}\right)$, entropic effects tend to destabilize the dinuclear heteroleptic complexes. As a result, homoleptic mononuclear complexes, i.e. $\left[\mathrm{Cu}(\mathrm{NN})_{2}\right]^{+}$and undefined dppa copper(I) complexes, start to appear in solution. In contrast, the heteroleptic coordination scenario is almost exclusively favored at lower temperatures. For most of the dinuclear complexes, the 10-membered dimetallacycle remains flexible and chair-to-chair interconversion occurs faster than the NMR timescale even at $-70^{\circ} \mathrm{C}$. In the particular case of the mpp derivative, the bulky phenyl substituent prevents the isomerization of the metallacycle and thus contributes to rigidify the structure. This
\end{abstract}

[a] Dr. J.-F. Nierengarten, Dr. I. Nierengarten, Dr. M. Holler, Laboratoire de Chimie des Matériaux Moléculaires, Université de Strasbourg et CNRS (LIMA - UMR 7042), Ecole Européenne de Chimie, Polymères et Matériaux,

25 rue Becquerel, 67087 Strasbourg Cedex 2, France

E-mail: nierengarten@unistra.fr http://nierengartengroup.com

[b] Dr. A. Sournia-Saquet, Dr. B. Delavaux-Nicot Laboratoire de Chimie de Coordination du CNRS (UPR 8241), Université de Toulouse (UPS, INPT),

205 Route de Narbonne, 31077 Toulouse Cedex 4, France

E-mail: beatrice.delavaux@lcc-toulouse.fr

[c] Dr. E. Leoni,

Laboratorio Tecnologie dei Materiali Faenza, ENEA

Via Ravegnana 186, 48018 Faenza (RA), Italy

[d] Dr. E. Leoni, Dr. F. Monti, Dr. N. Armaroli

Istituto per la Sintesi Organica e la Fotoreattività, Consiglio

Nazionale delle Ricerche

Via P. Gobetti 101, 40129 Bologna, Italy

E-mail: nicola.armaroli@isof.cnr.it

Supporting information for this article is given via a link at the end of the document. rigidification has a dramatic effect on the emission properties of this particular compound. The emission quantum yield of $\left[\mathrm{Cu}_{2}(\mu-\right.$ dppa $\left.)_{2}(\mathrm{mpp})_{2}\right]\left(\mathrm{BF}_{4}\right)_{2}$ is effectively one order of magnitude higher when compared to all the other complexes in this series (20\% vs. $0.3-1.7 \%$ in the solid state).

\section{Introduction}

Luminescent copper(I) complexes combining chelating bisphosphine ligands (PP) and aromatic diamine ligands such as 1,10-phenanthrolines or 2,2'-bipyridines have been intensively investigated in recent years owing to their potential for the preparation of light emitting device ${ }^{[1]}$ and dye sensitized solar cells. $^{[2]}$ Such compounds are also intensively used as photosensitizers for various photocatalytic reactions. ${ }^{[3]}$ While stable in the solid state, $[\mathrm{Cu}(\mathrm{PP})(\mathrm{NN})]^{+}$derivatives often undergo ligand exchange in solution and the coordination sphere around the copper(I) cation is not always easy to control. ${ }^{[4]}$ One of the major difficulties is to sufficiently increase steric hindrance without destabilizing the heteroleptic complex in order to prevent ligand distortion in the triplet metal-to-ligand charge transfer $\left({ }^{3} \mathrm{MLCT}\right)$ excited state. ${ }^{[3-4]}$ This is a key factor for the preparation of $[\mathrm{Cu}(\mathrm{PP})(\mathrm{NN})]^{+}$materials with long excited state lifetimes and high emission quantum yields. Whereas mononuclear $[\mathrm{Cu}(\mathrm{PP})(\mathrm{NN})]^{+}$ derivatives have been already intensively explored, ${ }^{[5-7]}$ related dinuclear copper(I) complexes with bridging PP ligands have been investigated to a lesser extent. ${ }^{[7-10]}$ For instance, dinuclear copper(I) complexes with two bridging bis(diphenylphosphino)methane (dppm) ligands have shown promising photophysical properties ${ }^{[9]}$ As part of this research, we became interested in using bis(diphenylphosphino)acetylene (dppa) as a non-chelating PP ligand for the preparation of $\left[\mathrm{Cu}_{2}(\mu-\right.$ dppa $\left.)_{2}(\mathrm{NN})_{2}\right]\left(\mathrm{BF}_{4}\right)_{2}$ derivatives. To the best of our knowledge, only a few dppa-containing heteroleptic dinuclear copper(I) complexes have been prepared so far and previous investigations were mainly focused on their solid-state structures. ${ }^{[10]}$ UV-Vis absorption features have been also briefly outlined by Fazal et al., ${ }^{[10 \mathrm{~b}]}$ while the stability of $\left[\mathrm{Cu}_{2}(\mu-\mathrm{dppa})_{2}(\mathrm{NN})_{2}\right]\left(\mathrm{BF}_{4}\right)_{2}$ derivatives in solution and their luminescence properties have not yet been studied.

\section{Results and Discussion}

Synthesis and Characterization. Dinuclear copper(I) complexes combining dppa-bridging ligands with 2,2'-bipyridines or 1,10- 
phenanthrolines have been already reported. ${ }^{[10]}$ These compounds have been prepared by treatment of the triply-bridged dicopper(I) complex of dppa, ie. [Cu2 $\left.(\mu-\mathrm{dppa})_{3}\left(\mathrm{CH}_{3} \mathrm{CN}\right)_{2}\right]\left(\mathrm{BF}_{4}\right)_{2},{ }^{[11]}$ with the appropriate NN ligand. As shown in Scheme 1, we found that $\left[\mathrm{Cu}_{2}(\mu \text {-dppa })_{2}(\mathrm{NN})_{2}\right]\left(\mathrm{BF}_{4}\right)_{2}$ derivatives can be conveniently prepared from the dppa ligand. Specifically, an equimolar mixture of dppa and $\left[\mathrm{Cu}\left(\mathrm{CH}_{3} \mathrm{CN}\right)_{4}\right]\left(\mathrm{BF}_{4}\right)$ in $\mathrm{CH}_{2} \mathrm{Cl}_{2} / \mathrm{CH}_{3} \mathrm{CN}$ (7:3) was stirred for 30 min., then the appropriate NN ligand (1 equiv.) was added [NN = 1,10-phenanthroline (phen), neocuproine (dmp), bathophenanthroline (Bphen), bathocuproine (Bdmp) or 2-phenyl1,10-phenanthroline (mpp)]. After $1 \mathrm{~h}$, the solvents were evaporated. ${ }^{1} \mathrm{H}$ and ${ }^{31} \mathrm{P}$ NMR analysis of the crude products thus obtained indicated the nearly quantitative formation of the $\left[\mathrm{Cu}_{2}(\mu-\right.$ dppa $\left.)_{2}(\mathrm{NN})_{2}\right]\left(\mathrm{BF}_{4}\right)_{2}$ derivatives. It is worth noting that traces of the homoleptic complexes, i.e. $\left[\mathrm{Cu}(\mathrm{NN})_{2}\right]\left(\mathrm{BF}_{4}\right)$, were observed in the crude mixtures obtained from the 2,9-disubstituted-1,10phenanthroline ligands ( $\mathrm{dmp}$ and Bdmp) as well as from the 2monosubstituted one (mpp). All heteroleptic complexes $\left[\mathrm{Cu}_{2}(\mu-\right.$ dppa $\left.)_{2}(\mathrm{NN})_{2}\right]\left(\mathrm{BF}_{4}\right)_{2}$ were then obtained pure as crystalline solids by vapor diffusion of $\mathrm{Et}_{2} \mathrm{O}$ into a $\mathrm{CH}_{2} \mathrm{Cl}_{2}$ solution of the crude product. Complexes $\left[\mathrm{Cu}_{2}(\mu-\mathrm{dppa})_{2}(\mathrm{NN})_{2}\right]\left(\mathrm{BF}_{4}\right)_{2}$ were thus isolated in yields ranging from 88 to $94 \%$.
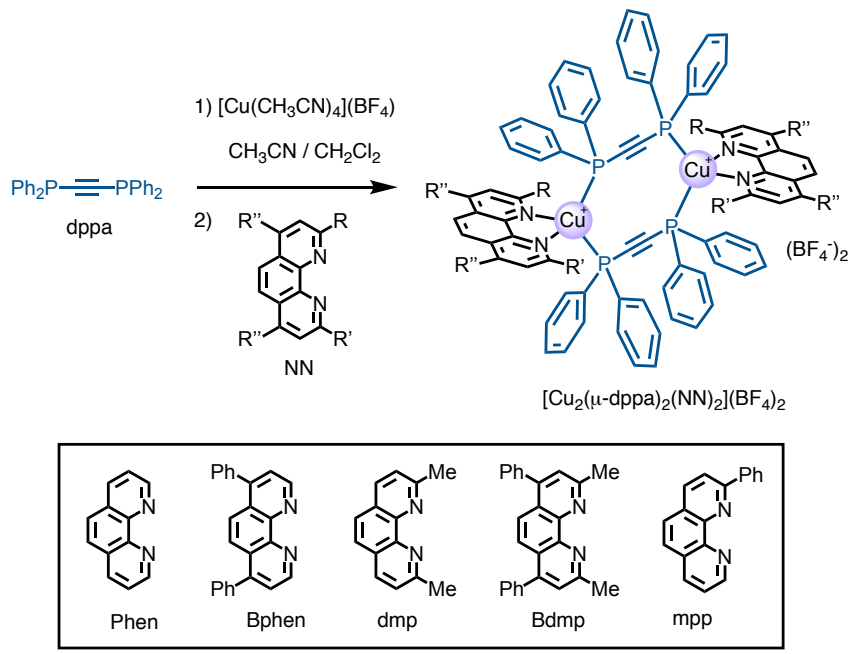

Scheme 1. Preparation of the dinuclear $\mathrm{Cu}(\mathrm{I})$ complexes from dppa and various phenanthroline ligands.

X-ray quality crystals were obtained for four $\left[\mathrm{Cu}_{2}(\mu-\right.$ $\left.\mathrm{dppa})_{2}(\mathrm{NN})_{2}\right]\left(\mathrm{BF}_{4}\right)_{2}$ derivatives (NN = phen, $\mathrm{dmp}$, Bphen and $\mathrm{mpp}$ ). The $X$-ray crystal structures of the dications are depicted in Figure 1. In all the cases, the 10-membered dimetallacycle is centrosymmetrical and adopts a chair-like conformation. Four phenyl groups of the dppa ligand are in an axial orientation while the four others are in an equatorial orientation. It can be also noted that two slightly different $\left[\mathrm{Cu}_{2}(\mu \text {-dppa })_{2}(\text { Bphen })_{2}\right]^{2+}$ dications are present in the crystal lattice of $\left[\mathrm{Cu}_{2}(\mu-\right.$ dppa $\left.)_{2}(\text { Bphen })_{2}\right]\left(\mathrm{BF}_{4}\right)_{2} .\left(\mathrm{C}_{6} \mathrm{H}_{6}\right)$ but bond lengths and bond distances remain in the same range for both (Table S5). The four structures are similar to the ones already reported in the literature for analogous $\left[\mathrm{Cu}_{2}(\mu-\mathrm{dppa})_{2}(\mathrm{NN})_{2}\right]^{2+}$ derivatives ${ }^{[10]}$ and detailed analysis of the coordination sphere around the $\mathrm{Cu}^{+}$cations can be found in the ESI (Figures S1-4, Tables S1-5).
(A)

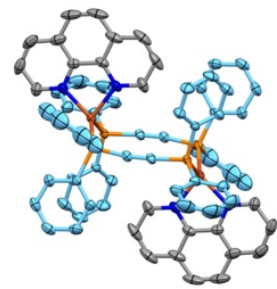

(C)

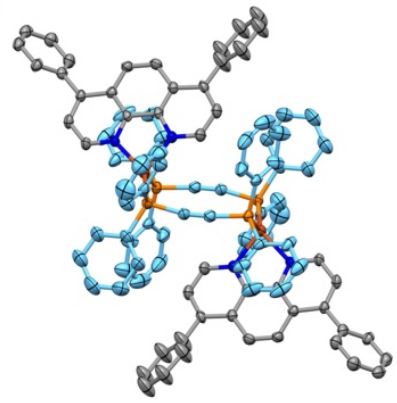

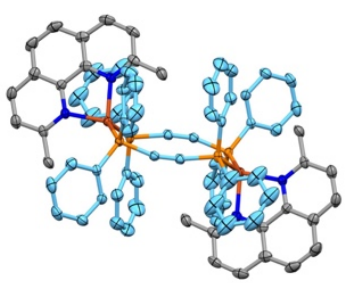

(D)

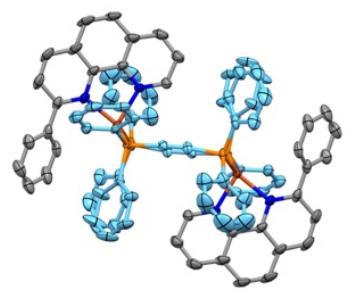

Figure 1. (A) Structure of $\left[\mathrm{Cu}_{2}(\mu-\mathrm{dppa})_{2}(\text { phen })_{2}\right]\left(\mathrm{BF}_{4}\right)_{2} \cdot\left(\mathrm{CH}_{2} \mathrm{Cl}_{2}\right) ;(\mathrm{B})$ Structure of $\left[\mathrm{Cu}_{2}(\mu \text {-dppa })_{2}(\mathrm{dmp})_{2}\right]\left(\mathrm{BF}_{4}\right)_{2} \cdot\left(\mathrm{CH}_{2} \mathrm{Cl}_{2}\right) ; \quad$ (C) Structure of $\left[\mathrm{Cu}_{2}(\mu \text {-dppa })_{2}\right.$ (Bphen) $\left.)_{2}\right]\left(\mathrm{BF}_{4}\right)_{2} .\left(\mathrm{C}_{6} \mathrm{H}_{6}\right)$; (D) Structure of $\left[\mathrm{Cu}_{2}(\mu-\mathrm{dppa})_{2}(\mathrm{mpp})_{2}\right]\left(\mathrm{BF}_{4}\right)_{2} \cdot\left(\mathrm{CH}_{2} \mathrm{Cl}_{2}\right)$ (ORTEP plots; C: gray for the NN ligand and pale blue for dppa, $\mathrm{N}$ : blue, $\mathrm{P}$ : orange; $\mathrm{Cu}$ : dark orange; the $\mathrm{H}$ atoms, the counter anions and the cocrystallized solvent molecules are omitted for clarity; in the case of $\left[\mathrm{Cu}_{2}(\mu-\right.$ dppa $\left.)_{2}(B p h e n)_{2}\right]\left(B_{4}\right)_{2} \cdot\left(\mathrm{C}_{6} \mathrm{H}_{6}\right)$, only one of the two centro-symmetrical dications present in the crystal lattice is represented; thermal ellipsoids are shown at the $50 \%$ probability level).

Notable intramolecular $\mathrm{CH}-\pi$ and/or $\pi-\pi$ interactions can be observed in the $\left[\mathrm{Cu}_{2}(\mu \text {-dppa })_{2}(\mathrm{NN})_{2}\right]^{2+}$ moieties, however close inspection of the structures revealed no particular negative steric effects that could destabilize the dinuclear complexes. These compounds are indeed quite stable in solution (vide infra). It is also worth noticing that the presence of substituents on the 2,9positions of the phenanthroline ligands does not generate significative steric hindrance as observed in the case of some $[\mathrm{Cu}(\mathrm{PP})(\mathrm{dmp})]^{+}$derivatives prepared from dmp and various bisphosphine ligands (PP) such as 1,2bis(diphenylphosphino)ethane (dppe) or 1,3bis(diphenylphosphino)propane (dppp). ${ }^{[7]}$ In the case of the dmp derivative, the metallacycle adopts a more flattened structure preventing negative steric effects due to the presence of the methyl groups. The chair dihedral angle of the 10 -membered metallacycle is about $37^{\circ}$ for the dmp derivative when compared to $65^{\circ}$ for the phen analogue. As a result, the $\mathrm{Cu}-\mathrm{Cu}$ distance is significantly larger for the dmp derivative [6.621(1) A] when compared to the phen derivative $[6.0606(7) \AA]$. In the case of $\left[\mathrm{Cu}_{2}(\mu-\mathrm{dppa})_{2}(\mathrm{mpp})_{2}\right]^{2+}$, the two mpp ligands are oriented in an Anti relative orientation and the metallacycle easily adapts its conformation to accommodate the bulky 2-phenyl substituent of the NN ligands. Close inspection of the packing reveals infinite supramolecular chains of $\left[\mathrm{Cu}_{2}(\mu-\mathrm{dppa})_{2}(\mathrm{mpp})_{2}\right]^{2+}$ dications 
through phenanthroline-phenanthroline $\pi-\pi$ interactions (Figure 2). Similar intermolecular interactions are also observed for the corresponding dmp and Bphen derivatives (Figures S2B and $\mathrm{S} 4 \mathrm{C})$. In contrast, no phenanthroline-phenanthroline interactions are observed in the crystal lattice of $\left[\mathrm{Cu}_{2}(\mu \text {-dppa })_{2}(\text { phen })_{2}\right]\left(\mathrm{BF}_{4}\right)_{2}$. In this particular case, each phenanthroline moiety is interacting with the phenyl unit of a dppa ligand from a neighboring dication (Figure S1B). Overall, crystal packing analysis reveals a network of $\mathrm{CH}-\pi$ and $\pi-\pi$ interactions for all the four complexes. The remarkably higher emission quantum yield observed for the mpp derivative in the solid state when compared to the other compounds is therefore not simply related to differences in the packing forces leading to a more rigid structure (vide infra). The rigidification of the dimetallacycle may therefore arise from intrinsic structural parameters resulting from the presence of the bulky 2-substituent on the phenanthroline ligand in the case of mpp. This prompted us to perform detailed NMR investigations in solution to further understand the structural flexibility/rigidity of the metallacycles as a function of the NN ligands (Figures S5-9).

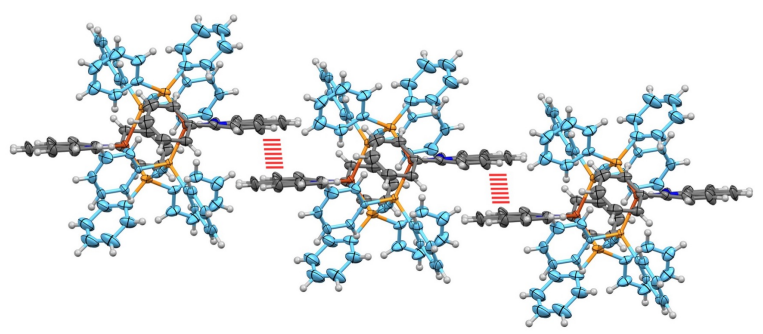

Figure 2. Stacking within the $\left[\mathrm{Cu}_{2}(\mu \text {-dppa })_{2}(\mathrm{mpp})_{2}\right]\left(\mathrm{BF}_{4}\right)_{2} \cdot\left(\mathrm{CH}_{2} \mathrm{Cl}_{2}\right)_{2}$ lattice, the close contacts between the mpp ligands of neighboring dications are highlighted by red lines (ORTEP representation; $\mathrm{C}$ : gray for the $\mathrm{dmp}$ ligand and pale blue for dppa, $\mathrm{N}$ : blue, $\mathrm{P}$ : orange; $\mathrm{Cu}$ : dark orange, $\mathrm{H}$ : white).

${ }^{1} \mathrm{H}$ and ${ }^{31} \mathrm{P}$ NMR spectra recorded in $\mathrm{CD}_{2} \mathrm{Cl}_{2}$ at $25^{\circ} \mathrm{C}$ for the $\left[\mathrm{Cu}_{2}(\mu \text {-dppa })_{2}(\mathrm{NN})_{2}\right]\left(\mathrm{BF}_{4}\right)_{2}$ derivatives prepared from unsubstituted 1,10-phenanthroline ligands $(\mathrm{NN}=$ phen and Bphen) were fully consistent with the proposed structures and revealed no particular evolution with time. In contrast, the behavior of the corresponding derivatives prepared from $\mathrm{dmp}$, Bdmp and mpp was different. Whereas freshly prepared $\mathrm{CD}_{2} \mathrm{Cl}_{2}$ solutions only revealed the presence of $\left[\mathrm{Cu}_{2}(\mu-\right.$ $\left.\mathrm{dppa})_{2}(\mathrm{NN})_{2}\right]\left(\mathrm{BF}_{4}\right)_{2}$, traces of the homoleptic complexes, i.e. $\left[\mathrm{Cu}(\mathrm{NN})_{2}\right]\left(\mathrm{BF}_{4}\right)$, appeared slowly with time together with traces of undefined copper(I) complexes of dppa. After 30 minutes, the heteroleptic/homoleptic ratio deduced from the NMR was exactly the same as the one observed in the corresponding crude mixtures (vide supra). These observations show that ligand exchange reactions are taking place in solution. The equilibrium between the different complexes is likely governed by the relative thermodynamic stability of the various possible species. At the equilibrium, the $\left[\mathrm{Cu}_{2}(\mu-\mathrm{dppa})_{2}(\mathrm{NN})_{2}\right]\left(\mathrm{BF}_{4}\right)_{2}(\mathrm{NN}=\mathrm{dmp}, \mathrm{Bdmp}$ or $\mathrm{mpp})$ remain largely major in solution at room temperature and only traces of the corresponding $\left[\mathrm{Cu}(\mathrm{NN})_{2}\right]\left(\mathrm{BF}_{4}\right)$ are detected $(1$ to $3 \%$ depending on the NN ligands). Given the remarkably high thermodynamic stability of $\left[\mathrm{Cu}(\mathrm{NN})_{2}\right]^{+}$derivatives obtained from 2,9-substituted-1,10-phenanthroline $(\log \beta=10-12),{ }^{[12]}$ the stability of $\left[\mathrm{Cu}_{2}(\mu-\mathrm{dppa})_{2}(\mathrm{NN})_{2}\right]^{2+}$ must be very high as well. On the other hand, a substantially low thermodynamic stability of the copper(I) complexes of dppa may also contribute to displace the equilibrium towards the formation of the heteroleptic complexes. In the case of 2,9-unsubstituted-1,10-phenanthroline ligands (phen and Bphen), the corresponding $\left[\mathrm{Cu}(\mathrm{NN})_{2}\right]^{+}$derivatives are less stable and therefore unable to compete with the formation of the heteroleptic $\left[\mathrm{Cu}_{2}(\mu-\mathrm{dppa})_{2}(\mathrm{NN})_{2}\right]^{2+}$ complexes. This explains the apparent absence of ligand exchange in solutions for the phen and Bphen derivatives at room temperature. ${ }^{1} \mathrm{H}$ NMR spectra of $\left[\mathrm{Cu}_{2}(\mu \text {-dppa })_{2}(\text { phen })_{2}\right]\left(\mathrm{BF}_{4}\right)_{2}$ were also recorded at higher temperatures in $\mathrm{CDCl}_{2} \mathrm{CDCl}_{2}$ (Figure S5D). Changes in chemical shifts for the diagnostic signals of the phen ligand as a function of temperature are indicative for a dynamic coordination/decoordination. At the same time, the presence of undefined copper $(\mathrm{I})$ complexes of dppa is detected at higher temperature. By increasing the temperature, decoordination is favored. Simultaneously, $\left[\mathrm{Cu}_{2}(\mu-\mathrm{dppa})_{2}(\text { phen })_{2}\right]\left(\mathrm{BF}_{4}\right)_{2}$ is also progressively destabilized by negative entropic effects. As long as the temperature does not exceed $80^{\circ} \mathrm{C}$, the copper $(\mathrm{I})$ complexes remain stable. By further increasing the temperature, $\left[\mathrm{Cu}(\text { phen })_{2}\right]^{+}$ starts to appear in the solution. This compound is quickly irreversibly oxidized in $\left[\mathrm{Cu}(\text { phen })_{2}\right]^{2+}$ as attested by the green color of the solution and the broadening of all the NMR signals due to the presence of paramagnetic copper(II) cations. To further understand the stability of these compounds, variable temperature ${ }^{1} \mathrm{H}$ and ${ }^{31} \mathrm{P}$ NMR studies were also conducted with $\left[\mathrm{Cu}_{2}(\mu-\mathrm{dppa})_{2}(\mathrm{dmp})_{2}\right]\left(\mathrm{BF}_{4}\right)_{2}$. (Figures $3 \mathrm{~A}-\mathrm{B}$ and S7E-H). As observed in the case of the phen derivative, the significant changes in chemical shift as a function of the temperature are indicative for dynamic ligand coordination/decoordination. By increasing the temperature, $\left[\mathrm{Cu}_{2}(\mu-\mathrm{dppa})_{2}(\mathrm{dmp})_{2}\right]^{2+}$ is substantially destabilized by entropic effects and the formation of the mononuclear homoleptic complex $\left[\mathrm{Cu}(\mathrm{dmp})_{2}\right]^{+}$becomes more favorable. As a result, the equilibrium is displaced towards the homoleptic complexes at higher temperature. This effect is perfectly reversible and the ${ }^{1} \mathrm{H}$ NMR spectra recorded at $25^{\circ} \mathrm{C}$ upon cooling is identical to the one recorded before heating. These observations clearly show that the heteroleptic/homoleptic ratio results from thermodynamic effects. In other words, the ratio of the different complexes reflects their relative thermodynamic stabilities at a given temperature. As shown in Figure 3B, ${ }^{1} \mathrm{H}$ NMR spectra recorded for $\left[\mathrm{Cu}_{2}(\mu-\mathrm{dppa})_{2}\left(\mathrm{dmp}_{2}\right]\left(\mathrm{BF}_{4}\right)_{2}\right.$ between 25 and $-70^{\circ} \mathrm{C}$ revealed only small changes in chemical shift. At $-70^{\circ} \mathrm{C}$, a single set of signals is observed for all the phenyl units of the dppa ligands thus showing that the axial and equatorial phenyl moieties still exchange their position faster than the NMR timescale under these conditions. The torsional strain in the chair conformation of the 10-membered metallacycle observed in the X-ray crystal structure must be rather small and the chair-to-chair interconversion is therefore easy. In other words, the 10membered metallacycle is quite flexible in this particular case. 

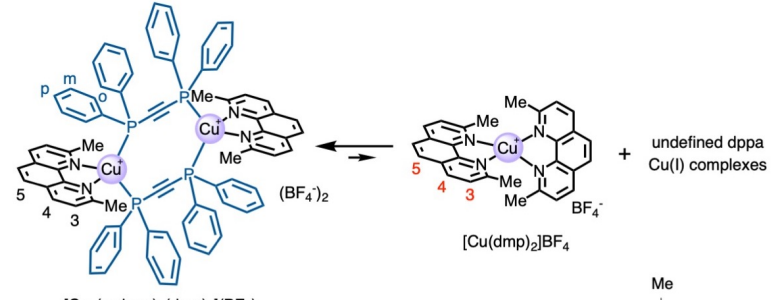

$\left[\mathrm{Cu}_{2}(\mu-\mathrm{dppa})_{2}(\mathrm{dmp})_{2}\right]\left(\mathrm{BF}_{4}\right)_{2}$

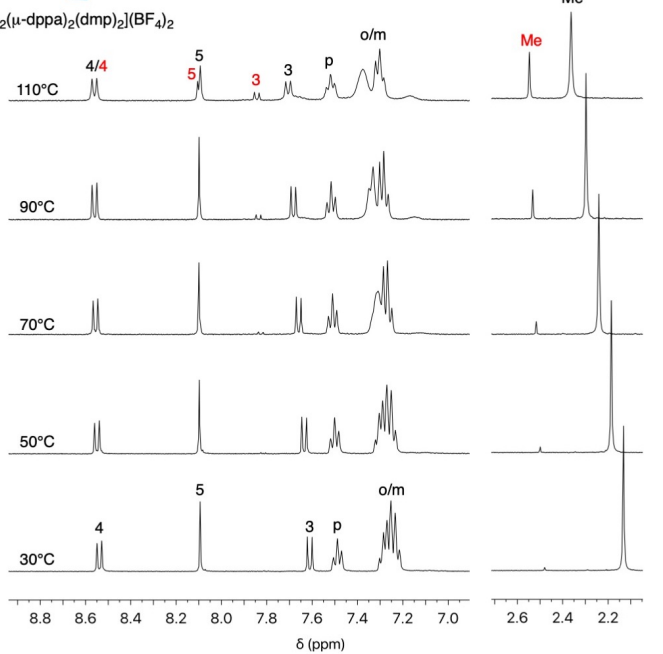

Figure 3A. ${ }^{1} \mathrm{H} \quad \mathrm{NMR}$ spectra $\left(400 \mathrm{MHz}, \mathrm{CDCl}_{2} \mathrm{CDCl}_{2}\right)$ of $\left[\mathrm{Cu}_{2}(\mu-\right.$ $\left.\mathrm{dppa})_{2}(\mathrm{dmp})_{2}\right]\left(\mathrm{BF}_{4}\right)_{2}$ recorded at different temperatures.
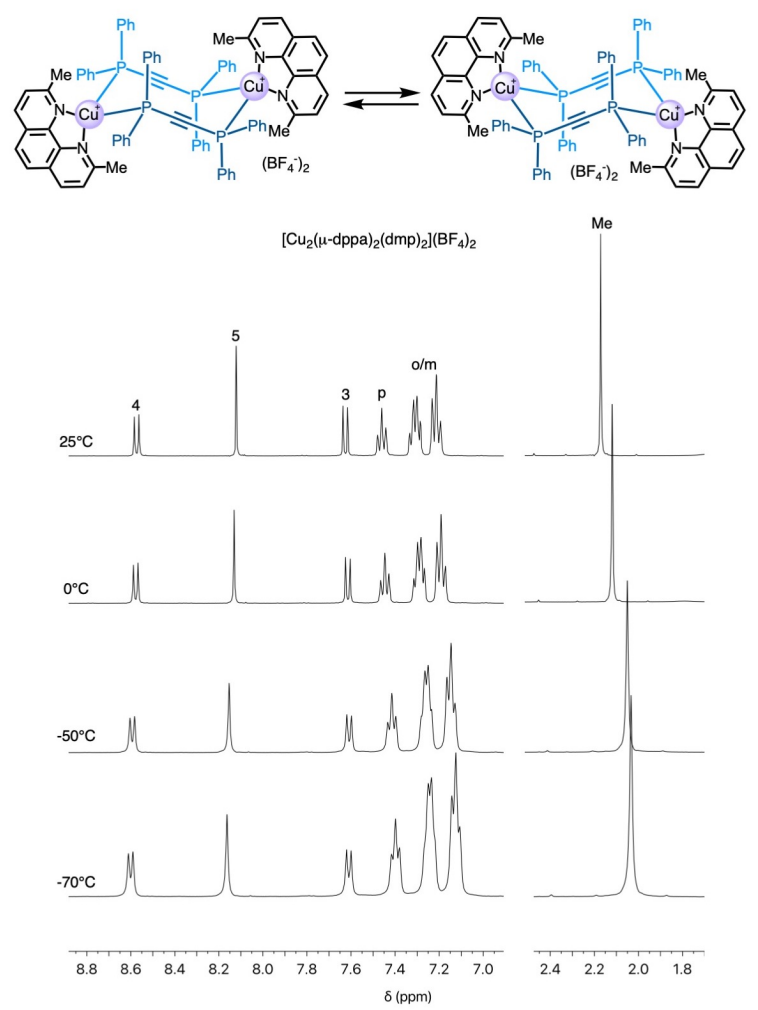

Figure 3B. ${ }^{1} \mathrm{H}$ NMR spectra $\left(400 \mathrm{MHz}, \mathrm{CD}_{2} \mathrm{Cl}_{2}\right)$ of $\left[\mathrm{Cu}_{2}(\mu \text {-dppa })_{2}(\mathrm{dmp})_{2}\right]\left(\mathrm{BF}_{4}\right)_{2}$ recorded at different temperatures. At $-70^{\circ} \mathrm{C}$, a single set of signals is observed for all the phenyl units of the dppa ligands thus showing that the axial and equatorial phenyl moieties still exchange their position faster than the NMR timescale under these conditions.

acting as a latch capable of preventing the chair-to-chair interconversion and thus contributes to rigidify the conformation of the 10-membered metallacycle. This is also fully consistent with the conformation observed in the X-ray crystal structure of [ $\mathrm{Cu}_{2}(\mu-$ $\left.\mathrm{dppa})_{2}(\mathrm{mpp})_{2}\right]\left(\mathrm{BF}_{4}\right)_{2}$. These structural effects resulting from the presence of the bulky phenyl group are most likely at the origin of the remarkable photophysical properties of $\left[\mathrm{Cu}_{2}(\mu-\right.$ $\left.\mathrm{dppa})_{2}(\mathrm{mpp})_{2}\right]\left(\mathrm{BF}_{4}\right)_{2}$ in the solid state (vide infra).

Electrochemistry. The electrochemical properties of $\left[\mathrm{Cu}_{2}(\mu-\right.$ $\left.\mathrm{dppa})_{2}(\mathrm{NN})_{2}\right]\left(\mathrm{BF}_{4}\right)_{2}(\mathrm{NN}=$ phen, dmp, Bphen, Bdmp or $\mathrm{mpp})$ and dppa were determined by cyclic voltammetry (CV) and Osteryoung Square Wave Voltammetry (OSWV). All the experiments were performed at room temperature in $\mathrm{CH}_{2} \mathrm{Cl}_{2}$ solutions containing tetra $n$-butylammonium tetrafluoroborate $(0.10 \mathrm{M})$ as supporting electrolyte and ferrocene $(\mathrm{Fc})$ as internal reference, with a Pt wire as the working electrode and a saturated calomel electrode (SCE) as a reference. Potential data for all of the compounds are collected in Table 1 and the voltammograms are shown in Figures 5 and S11-S16. low temperatures. The axial and equatorial phenyl moieties exchange their positions under these conditions as the mpp decoordination does not take place anymore at low temperature. On the other hand, the phenyl group of the mpp ligands is likely 


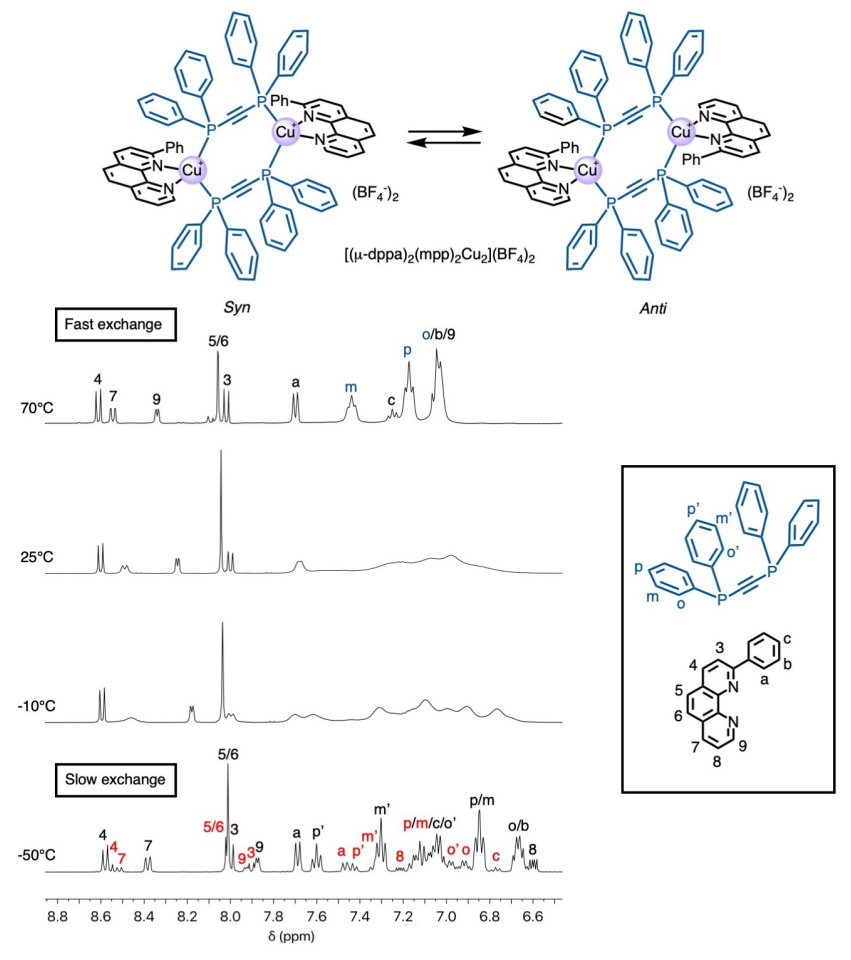

Figure 4. ${ }^{1} \mathrm{H}$ NMR spectra $(400 \mathrm{MHz})$ of $\left[\mathrm{Cu}_{2}(\mu-\mathrm{dppa})_{2}(\mathrm{mpp})_{2}\right]\left(\mathrm{BF}_{4}\right)_{2}$ recorded at $70^{\circ} \mathrm{C}$ in $\mathrm{CDCl}_{2} \mathrm{CDCl}_{2}$ and at $-50,-10$ and $25^{\circ} \mathrm{C}$ in $\mathrm{CD}_{2} \mathrm{Cl}_{2}$. At $70^{\circ} \mathrm{C}$, the dynamic exchange between the Syn and Anti isomers through mpp decoordination is faster than the NMR timescale. At $-50^{\circ} \mathrm{C}$, the isomerization is slower than the NMR timescale and NMR signals of the two isomers are observed (the assignment is indicated in black for the major isomer and in red for the minor one).

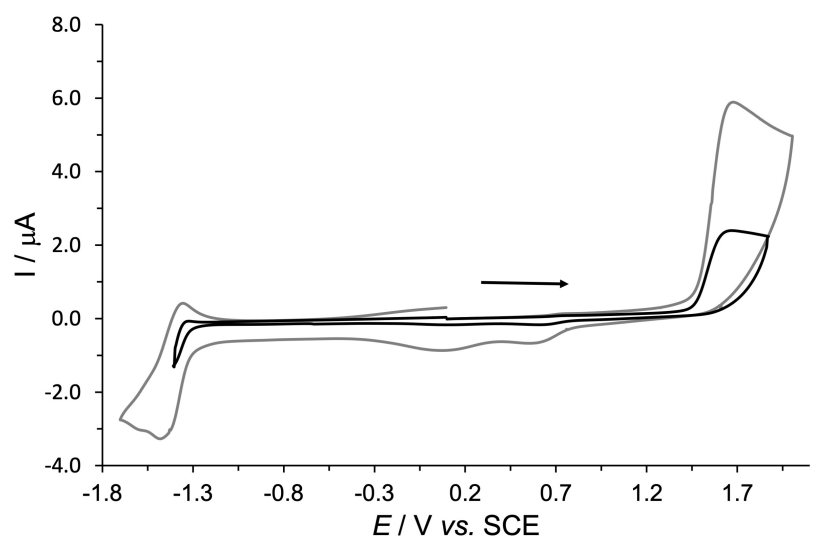

Figure 5. Representative cyclic voltammograms of $\left[\mathrm{Cu}_{2}(\mu-\mathrm{dppa})_{2}(\mathrm{mpp})_{2}\right]\left(\mathrm{BF}_{4}\right)_{2}$ on a Pt electrode in $\mathrm{CH}_{2} \mathrm{Cl}_{2}+0.1 \mathrm{M}\left[n \mathrm{Bu}_{4} \mathrm{~N}\right]\left[\mathrm{BF}_{4}\right]$ at a scan rate of $0.2 \mathrm{~V} / \mathrm{s}$ (black curve) and $1 \mathrm{~V} / \mathrm{s}$ (gray curve).
Table 1. Selected electrochemical data of dppa and $\left[\mathrm{Cu}_{2}(\mu-\right.$

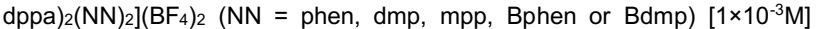
determined by OSWV on a $\mathrm{Pt}$ working electrode in $\mathrm{CH}_{2} \mathrm{Cl}_{2}+0.1 \mathrm{M}$ $\left[n \mathrm{Bu}_{4} \mathrm{~N}\right]\left[\mathrm{BF}_{4}\right]$ at room temperature. ${ }^{[a, b]}$ Ferrocene has been used as internal reference.

\begin{tabular}{ccc}
\hline & Oxidation & Reduction \\
\hline dppa & +1.53 & \\
{$\left[\mathrm{Cu}_{2}(\mu \text {-dppa })_{2}(\text { phen })_{2}\right]\left(\mathrm{BF}_{4}\right)_{2}$} & $+1.46^{[\mathrm{c}]}$ & -1.42 \\
{$\left[\mathrm{Cu}_{2}(\mu \text {-dppa })_{2}(\mathrm{dmp})_{2}\right]\left(\mathrm{BF}_{4}\right)_{2}$} & +1.66 & -1.48 \\
{$\left[\mathrm{Cu}_{2}(\mu-\mathrm{dppa})_{2}(\mathrm{mpp})_{2}\right]\left(\mathrm{BF}_{4}\right)_{2}$} & +1.59 & $-1.37^{[\mathrm{e}]}$ \\
{$\left[\mathrm{Cu}_{2}(\mu-\mathrm{dppa})_{2}(\mathrm{Bphen})_{2}\right]\left(\mathrm{BF}_{4}\right)_{2}$} & $+1.75^{[\mathrm{d}]}$ & $-1.36^{[\mathrm{f}]}$ \\
{$\left[\mathrm{Cu}_{2}(\mu-\mathrm{dppa})_{2}(\mathrm{Bdmp})_{2}\right]\left(\mathrm{BF}_{4}\right)_{2}$} & +1.69 & $-1.42^{[\mathrm{g}]}$ \\
\hline
\end{tabular}

[a] OSWVs were obtained using a sweep width of $20 \mathrm{mV}$, a frequency of 20 $\mathrm{Hz}$, and a step potential of $5 \mathrm{mV}$. [b] Potential values in Volt $v s$. SCE (Fc+/Fc is observed at $0.55 \mathrm{~V} \pm 0.01 \mathrm{~V}$ vs. SCE). [c] Maximum of a very broad peak starting at ca. $1.25 \mathrm{~V}$. [d] Maximum of a very broad peak starting at ca. 1.40 V. [e] Starting the $C V$ in reduction induces the formation of a new species detected as a minor wave in the oxidation part around $0.7 \mathrm{~V}$ and tentatively assigned to $\left[\mathrm{Cu}(\mathrm{mpp})_{2}\right]^{+}$(See SI, Fig 15C). [f] Quasi-reversible process observed by $\mathrm{CV}$ at around $5 \mathrm{~V} / \mathrm{s}$. (See SI, Fig. 13C). [g] Complex process showing two main components at high scan rate (See SI, Fig. 14E).

In all the cases, the first oxidation process is attributed to the $\mathrm{Cu}(\mathrm{II}) / \mathrm{Cu}(\mathrm{I})$ redox couple and there is no evidence for electronic interactions between the two $\mathrm{Cu}(\mathrm{I})$ centers as they are simultaneously oxidized. Cyclic voltammetry revealed also an electrochemical instability for all the $\left[\mathrm{Cu}_{2}(\mu \text {-dppa })_{2}(\mathrm{NN})_{2}\right]\left(\mathrm{BF}_{4}\right)_{2}$ derivatives. This instability is most likely related with the concomitant oxidation of the dppa ligand leading to decomposition of the complexes upon oxidation. The decomposition products are then observed in the backward scan giving rise to two broad waves around +0.6 and $+0.2 \mathrm{~V} v s$. SCE. In the cathodic region, all the $\left[\mathrm{Cu}_{2}(\mu-\mathrm{dppa})_{2}(\mathrm{NN})_{2}\right]\left(\mathrm{BF}_{4}\right)_{2}$ derivatives revealed the typical electrochemical response of $[\mathrm{Cu}(\mathrm{NN})(\mathrm{PP})]^{+}$derivatives ${ }^{[9,13-14]}$ and the first reduction process is likely centered on the phenanthroline ligands.

Photophysical Properties. All the complexes are stable in air at room temperature in the solid state, keeping their chemical integrity for months. When dissolved in solution (deaerated $\left.\mathrm{CH}_{2} \mathrm{Cl}_{2}\right)$ three of them $\left[\mathrm{Cu}_{2}(\mu-\mathrm{dppa})_{2}(\mathrm{dmp})_{2}\right]^{2+}, \quad\left[\mathrm{Cu}_{2}(\mu-\right.$ dppa $\left.)_{2}(\mathrm{Bdmp})_{2}\right]^{2+}$, and $\left.\left[\mathrm{Cu}_{2}(\mu-\mathrm{dppa})_{2}(\mathrm{mpp})_{2}\right]^{2+}\right)$ tend to decompose after one hour, affording small amounts of the related $\left[\mathrm{Cu}(\mathrm{NN})_{2}\right]^{+}$homoleptic species, ${ }^{[7]}$ as shown by the rise of the redshifted metal-to-ligand-charge-transfer (MLCT) absorption features above $350 \mathrm{~nm}$ (Figure S17). ${ }^{[4]}$ The phen and Bphen complexes show better stability, but a marked decrease of the MLCT band intensity is anyhow observed within 24 hours (Figure S17). All these observations are consistent with the results deduced from the detailed NMR investigations (vide supra). 
The absorption spectra of the whole series recorded from freshly prepared $\mathrm{CH}_{2} \mathrm{Cl}_{2}$ solutions are in line with $[\mathrm{Cu}(\mathrm{NN})(\mathrm{PP})]^{+}$ coordination compounds previously reported (Figure 6). ${ }^{[4,9]}$ The strong bands observed in the UV region ( $260-290 \mathrm{~nm})$ stem from both the PP and NN ligands. The intensities of these ligandcentered (LC) bands are around twice as much as those observed for related mononuclear complexes $\left(6.5-11.5 \times 10^{4} \mathrm{M}^{-1} \mathrm{~cm}^{-1} \mathrm{vs}\right.$. $\left.\approx 4 \times 10^{4} \mathrm{M}^{-1} \mathrm{~cm}^{-1}\right)$. The spectral position of the bands depends on the specific diimine ligand: the addition of electron donating substituents in 2- or 2,9-positions of the phenanthroline unit or the conjugation effect of such substituents in 2- or 4,7- positions, cause red shift. ${ }^{[9]}$

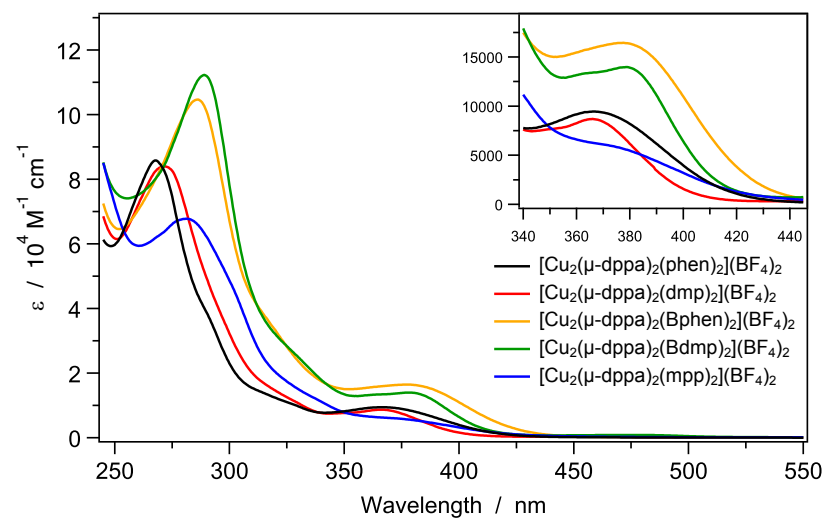

Figure 6. Absorption spectra in $\mathrm{CH}_{2} \mathrm{Cl}_{2}$ solution at $298 \mathrm{~K}$.

A second spectral feature is clearly evident for all of the compounds in the window across the UV / Vis regions (maxima at $370-380 \mathrm{~nm}$ ). It is characterized by lower absorption coefficients $\left(0.5-1.7 \times 10^{4} \mathrm{M}^{-1} \mathrm{~cm}^{-1}\right)$ and is attributed to MLCT transitions involving the NN ligands as acceptors. The increase of the conjugation through the introduction of phenyl groups in the 4,7 positions affords an increase of the spectral intensity and a red shift of the absorption maximum. ${ }^{[9]}$ On the contrary, when two methyl groups are placed in 2,9 positions, the molar absorption coefficient of the MLCT band is reduced with respect to the corresponding complex (i.e., dmp vs. phen and Bdmp vs. Bphen).

In Figure 7, the effects of the bridging $\mu$-dppa bisphosphine on the absorption profiles of $\left[\mathrm{Cu}_{2}(\mu-\mathrm{dppa})_{2}(\text { phen })_{2}\right]^{2+}$ and $\left[\mathrm{Cu}_{2}(\mu-\right.$ dppa $\left.)_{2}(B p h e n)_{2}\right]^{2+}$ are evidenced, with respect to analogous systems prepared from dppm previously investigated, namely $\left[\mathrm{Cu}_{2}(\mu \text {-dppm })_{2}(\text { phen })_{2}\right]\left(\mathrm{BF}_{4}\right)_{2}$ and $\left[\mathrm{Cu}_{2}(\mu \text {-dppm })_{2}(\mathrm{Bphen})_{2}\right]\left(\mathrm{BF}_{4}\right)_{2}$ (Scheme 2). ${ }^{[4,9,15]}$ The latter shows lower molar absorption coefficients and slightly blue-shifted MLCT features with respect to the $\mu$-dppa analogues. As we previously discussed, ${ }^{\left[{ }^{[9]}\right.}$ this trend is related to the different PP bite angle of the two bisphosphines, i.e. $\approx 138^{\circ}(\mathrm{dppm})$ vs. $118^{\circ}(\mathrm{dppa})$.

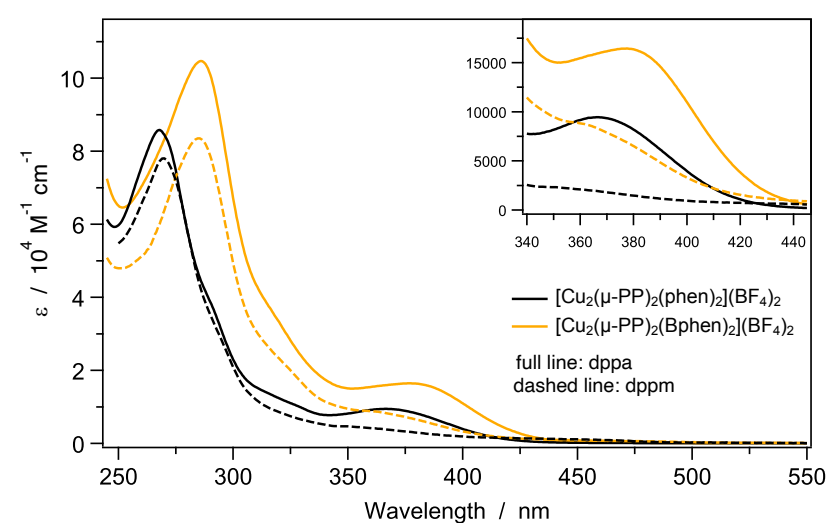

Figure 7. Comparison of the absorption spectra of $\mu$-dppa and $\mu$-dppm complexes, $\mathrm{CH}_{2} \mathrm{Cl}_{2}$ solution at $298 \mathrm{~K}$ (dppm data from Ref. 4).

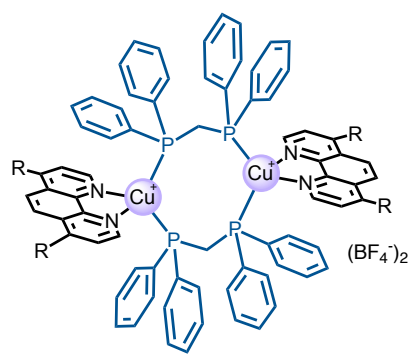

$\left[\mathrm{Cu}_{2}(\mu \text {-dppm })_{2}(\text { phen })_{2}\right]\left(\mathrm{BF}_{4}\right)_{2}(\mathrm{R}=\mathrm{H})$

[Cu2( $\mu$-dppm)2(Bphen)2](BF4)2 ( $\mathrm{R}=\mathrm{Ph})$

Scheme 2. Structure of $\left[\mathrm{Cu}_{2}(\mu-\mathrm{dppm})_{2}(\text { phen })_{2}\right]\left(\mathrm{BF}_{4}\right)_{2}$ and $\left[\mathrm{Cu}_{2}(\mu-\right.$ dppm $\left.)_{2}(\text { Bphen })_{2}\right]\left(B_{4}\right)_{2}$.

Only phen and Bphen exhibit (barely detectable) luminescence in solution; band maxima are located at 595 and $610 \mathrm{~nm}$, respectively (Figure S18). In line with consolidated literature, these emission bands are assigned to ${ }^{3} \mathrm{MLCT}$ excited states, possibly also undergoing thermally activated delayed fluorescence..$^{[4,14]}$ Photoluminescence quantum yields (PLQYs) and excited state lifetimes cannot be assessed due to the weakness of the emission signals. The effect of substantial ligand scrambling and/or decomposition of the complexes in solution is confirmed by the observation of emission bands at shorter wavelengths attributable to free phenanthroline ligands. Such ligands typically show intense fluorescence, ${ }^{[16-17]}$ therefore even minimal decomposition of the complexes (i.e., at early times after dissolution) can afford emission signals strong enough to hide the weak ${ }^{3} \mathrm{MLCT}$ bands under the spectral tails.

Emission in the solid state was investigated in powder samples placed in quartz tubes. It is well known that solid state luminescence spectra of $[\mathrm{Cu}(\mathrm{NN})(\mathrm{PP})]^{+}$are complicated and difficult to interpret. ${ }^{[9]}$ This is due to several factors such as the presence of closely lying excited states,,$^{[9]}$ the occurrence of interand intramolecular interactions (e.g. $\pi$-stacking from different parts of the ligand architecture $)^{[4]}$ and even the presence of different crystal structures that in turn may affect electronic excited states, ${ }^{[9,18]}$ often leading to spectral profiles that are a 
combination of multiple bands. Therefore, it is not surprising that the maxima of the emission spectra of the present family of compounds span across over $100 \mathrm{~nm}$ and the spectral profiles and widths vary substantially (Figure 8). All of the five complexes exhibit luminescence as powders (Table 2); the PLQY of four of them (phen, Bphen, dmp and dmBp complexes) is below $2 \%$, while the asymmetric $\left[\mathrm{Cu}_{2}(\mu-\mathrm{dppa})_{2}(\mathrm{mpp})_{2}\right]^{2+}$ shows a notable value of $20 \%$. This can be related to the presence of the phenyl functionality in the 2- position of the mpp ligand, which is locking the geometry of the 10-membered metallacycle as deduced from the NMR investigation. As a result, non-radiative deactivation pathways are more limited in this particular case..$^{[9]}$

The complex and multiple emission profiles are reflected in the detection of multiexponential luminescence decays, most of which with sizeable relative amplitude (Table 2). It can be observed that the stronger emitter in solid, $\left[\mathrm{Cu}_{2}(\mu \text {-dppa })_{2}(\mathrm{mpp})_{2}\right]^{2+}$, is characterized by the longer lifetimes. Finally, it is also interesting to highlight the influence of the PP ligand bite angle, by comparing the emission behavior of dppa-based complexes $v s$ dppm analogues ${ }^{[9]}$ (Figure 9). It turns out that the more compact and rigid coordination geometry imposed by dppm (wider bite angle) is less sensitive to the functionalization of the NN ligand in affecting the luminescence properties, whereas the longer dppa bridge affords a wider range of emission colors.

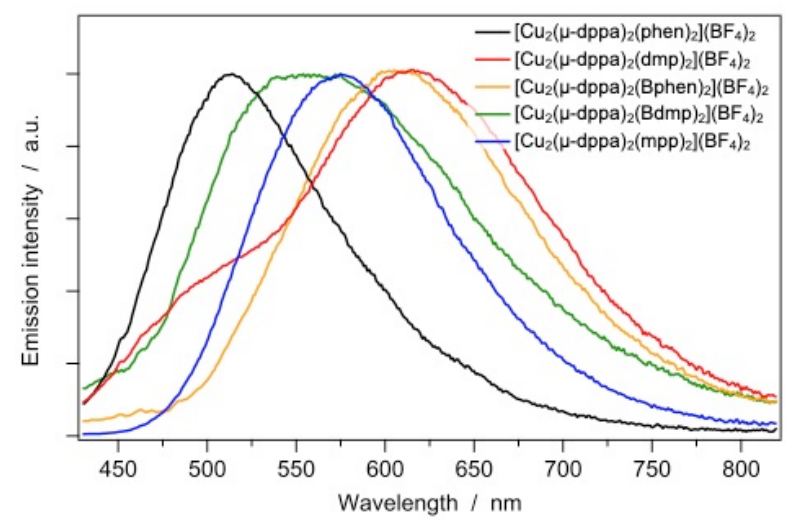

Figure 8. Normalized emission spectra of the complexes as powders at $298 \mathrm{~K}$. $\lambda_{\mathrm{exc}}=390 \mathrm{~nm}$.

Table 2. Photophysical data of $\left[\mathrm{Cu}_{2}(\mu-\mathrm{dppa})_{2}(\mathrm{NN})_{2}\right]\left(\mathrm{BF}_{4}\right)_{2}(\mathrm{NN}=$ phen, dmp, mpp, Bphen or Bdmp $)$ in the solid state $($ powders $)$ at $298 \mathrm{~K}\left(\lambda_{\mathrm{exc}}=370 \mathrm{~nm}\right)$.

\begin{tabular}{|c|c|c|c|c|c|}
\hline & \multicolumn{2}{|c|}{ Luminescence $^{[\mathrm{a}]}$} & \multicolumn{3}{|c|}{ Luminescence lifetime $^{[\mathrm{b}]}$} \\
\hline & $\lambda_{\mathrm{em}}$ & & $\tau_{1}$ & $\tau_{2}$ & $\tau_{2}$ \\
\hline & $(\mathrm{nm})$ & $(\%)$ & $(\mu \mathrm{s})$ & $(\mu s)$ & $(\mu \mathrm{s})$ \\
\hline$\left[\mathrm{Cu}_{2}(\mu-\mathrm{dppa})_{2}(\text { phen })_{2}\right]^{2+}$ & 513 & 0.6 & $0.495(80 \%)$ & $2.69(20 \%)$ & - \\
\hline$\left[\mathrm{Cu}_{2}(\mu-\mathrm{dppa})_{2}(\mathrm{dmp})_{2}\right]^{2+}$ & $617(515)$ & 1.7 & $1.93(44 \%)$ & $5.44(49 \%)$ & $20.70(7 \%)$ \\
\hline$\left[\mathrm{Cu}_{2}(\mu-\mathrm{dppa})_{2}(\text { Bphen })_{2}\right]^{2+}$ & 607 & 0.4 & $0.544(20 \%)$ & $1.98(55 \%)$ & $5.21(25 \%)$ \\
\hline$\left[\mathrm{Cu}_{2}(\mu-\mathrm{dppa})_{2}(\mathrm{Bdmp})_{2}\right]^{2+}$ & 560 & 0.3 & $1.64(30 \%)$ & $5.36(53 \%)$ & $29.36(17 \%)$ \\
\hline$\left[\mathrm{Cu}_{2}(\mu-\mathrm{dppa})_{2}(\mathrm{mpp})_{2}\right]^{2+}$ & 573 & 20.1 & $4.69(20 \%)$ & $9.47(57 \%)$ & $26.78(23 \%)$ \\
\hline
\end{tabular}

[a] $\lambda_{\mathrm{exc}}=390 \mathrm{~nm}$.

[b] $\lambda_{\mathrm{exc}}=373 \mathrm{~nm}$.

[c] Determined using an integration sphere (see Ref. 19). 


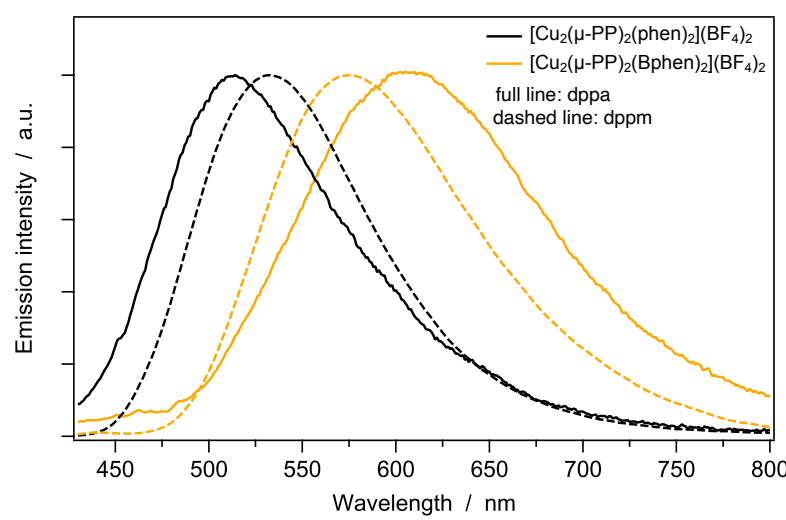

Figure 9. Effect of the PP bridging ligand on the emission spectra in solid, dppa (full line) and dppm (dashed line). $\lambda_{\text {exc }}=390 \mathrm{~nm}$ (dppm data from Ref. 4).

\section{Conclusions}

Five dinuclear copper(l) complexes have been prepared starting from dppa, $\left[\mathrm{Cu}\left(\mathrm{CH}_{3} \mathrm{CN}\right)_{4}\right]\left(\mathrm{BF}_{4}\right)$ and various 1,10-phenanthroline ligands (phen, Bphen, dmp, Bdmp and mpp). The resulting $\left[\mathrm{Cu}_{2}(\mu \text {-dppa })_{2}(\mathrm{NN})_{2}\right]\left(\mathrm{BF}_{4}\right)_{2}$ derivatives have been obtained in 88 to $94 \%$ yields. X-ray crystal structure analysis of four complexes revealed a chair-like conformation for the 10-membered dimetallacycle. For the systems with 2-9,-substituted 1,10phenanthroline ligands, the metallacycle adopts a flattened structure thus preventing negative steric effects. Detailed variable temperature NMR investigations have been carried out to evaluate the stability of these compounds in solution. Despite dynamic coordination/decoordination of the NN ligands, all the heteroleptic compounds are stable in solution at room temperature and homoleptic complexes resulting from ligand exchange reactions remain largely minor even for the 2,9disubstituted phenanthroline ligands. As long as the 2,9substituents of the NN ligands are small $(\mathrm{H}$ or $\mathrm{Me})$, the 10membered dimetallacycle remains flexible and chair-to-chair conversion is easy. In contrast, the bulky phenyl substituent prevents the chair-to-chair isomerization of the metallacycle and thus contribute to rigidify the structure of $\left[\mathrm{Cu}_{2}(\mu-\mathrm{dppa})_{2}(\mathrm{mpp})_{2}\right]^{2+}$. This rigidification has a dramatic effect on the emission properties of this particular compound. The emission quantum yield of $\left[\mathrm{Cu}_{2}(\mu \text {-dppa })_{2}(\mathrm{mpp})_{2}\right]\left(\mathrm{BF}_{4}\right)_{2}$ in the solid state is effectively one order of magnitude higher when compared to all the other complexes in this series..

\section{Experimental Section}

General. Reagents were purchased as reagent grade and used without further purification. Acetonitrile $\left(\mathrm{CH}_{3} \mathrm{CN}\right)$ and dichloromethane $\left(\mathrm{CH}_{2} \mathrm{Cl}_{2}\right)$ were distilled over $\mathrm{CaH}_{2}$ under Ar. All reactions were performed in standard glassware under an inert $\mathrm{Ar}$ atmosphere. Evaporation and concentration were done at water aspirator pressure and drying in vacuo at $10^{-2}$ Torr. NMR spectra were recorded with a Bruker AC 400 spectrometer with solvent peaks as reference. ESI-TOF mass spectra were carried out by the analytical service of the School of Chemistry (Strasbourg, France). Elemental analyses were performed by the analytical service at the Laboratoire de Chimie de Coordination (Toulouse, France).

General procedure for the preparation of $\left[\mathrm{Cu}_{2}(\mu \text {-dppa })_{2}\left(\mathrm{NN}_{2}\right)_{2}\left(\mathrm{BF}_{4}\right)_{2}\right.$. A solution of dppa (100 mg, $0.254 \mathrm{mmol}, 1$ equiv.) and $\left[\mathrm{Cu}\left(\mathrm{CH}_{3} \mathrm{CN}\right)_{4}\right]\left(\mathrm{BF}_{4}\right)$ (79.8 mg, $0.254 \mathrm{mmol}, 1$ equiv.) in a $7: 3 \mathrm{CH}_{2} \mathrm{Cl}_{2} / \mathrm{CH}_{3} \mathrm{CN}$ mixture $(15 \mathrm{~mL}$ ) was stirred for $0.5 \mathrm{~h}$, then the appropriate $\mathrm{NN}$ ligand $(0.254 \mathrm{mmol}, 1$ equiv. $)$ was added. After $1 \mathrm{~h}$, the solvents were evaporated. Heteroleptic complexes $\left[\mathrm{Cu}_{2}(\mu \text {-dppa })_{2}(\mathrm{NN})_{2}\right]\left(\mathrm{BF}_{4}\right)_{2}$ were obtained as crystalline solids by vapor diffusion of $\mathrm{Et}_{2} \mathrm{O}$ into a $\mathrm{CH}_{2} \mathrm{Cl}_{2}$ solution of the corresponding reaction mixture.

[Cu $\left.\mathbf{C u}_{2}(\mu \text {-dppa })_{2}(\text { phen })_{2}\right]\left(\mathrm{BF}_{4}\right)_{2}$. Isolated in $94 \%$ yield $(172 \mathrm{mg}, 0.119 \mathrm{mmol})$ as pale-yellow crystals. ${ }^{1} \mathrm{H}-\mathrm{NMR}\left(\mathrm{CD}_{2} \mathrm{Cl}_{2}, 400 \mathrm{MHz}, 293 \mathrm{~K}\right): 8.59$ (dd, $\mathrm{J}=$ 8 and $1 \mathrm{~Hz}, 4 \mathrm{H}), 8.52(\mathrm{dd}, J=4$ and $1 \mathrm{~Hz}, 4 \mathrm{H}), 8.07(\mathrm{~s}, 4 \mathrm{H}), 7.69(\mathrm{dd}, J=$ 8 and $4 \mathrm{~Hz}, 4 \mathrm{H}), 7.42(\mathrm{~m}, 8 \mathrm{H}), 7.27(\mathrm{~m}, 16 \mathrm{H}), 7.20(\mathrm{~m}, 16 \mathrm{H}) .{ }^{31} \mathrm{P}\left\{{ }^{1} \mathrm{H}\right\}-\mathrm{NMR}$ $\left(\mathrm{CD}_{2} \mathrm{Cl}_{2}, 293 \mathrm{~K}, 121.5 \mathrm{MHz}\right):-23.6$. ESI-MS: 637.1 ([ $\left.\mathrm{Cu}_{2}(\mathrm{dppa})_{2}(\text { phen })_{2}\right]^{2+}$, Calcd for $\mathrm{C}_{76} \mathrm{H}_{56} \mathrm{~N}_{4} \mathrm{P}_{4} \mathrm{Cu}_{2}$ : 637.102). Anal. Calcd for $\mathrm{C}_{76} \mathrm{H}_{56} \mathrm{~N}_{4} \mathrm{P}_{4} \mathrm{Cu}_{2} \mathrm{~B}_{2} \mathrm{~F}_{8}$ : C, 62.96; H, 3.89; N, 3.86. Found: C, 62.55; H, 3.35; N, 3.86.

$\left[\mathrm{Cu}_{2}(\mu \text {-dppa })_{2}(\mathrm{dmp})_{2}\right]\left(\mathrm{BF}_{4}\right)_{2}$. Isolated in $88 \%$ yield $(168 \mathrm{mg}, 0.112 \mathrm{mmol})$ as pale-yellow crystals. ${ }^{1} \mathrm{H}-\mathrm{NMR}\left(\mathrm{CD}_{2} \mathrm{Cl}_{2}, 400 \mathrm{MHz}, 293 \mathrm{~K}\right): 8.57(\mathrm{~d}, \mathrm{~J}=$ $8 \mathrm{~Hz}, 4 \mathrm{H}), 8.12(\mathrm{~s}, 4 \mathrm{H}), 7.62(\mathrm{~d}, J=8 \mathrm{~Hz}, 4 \mathrm{H}), 7.46(\mathrm{~m}, 8 \mathrm{H}), 7.31(\mathrm{~m}, 16 \mathrm{H})$, $7.21(\mathrm{~m}, 16 \mathrm{H}), 2.17(\mathrm{~s}, 12 \mathrm{H}) .{ }^{31} \mathrm{P}\left\{{ }^{1} \mathrm{H}\right\}-\mathrm{NMR}\left(\mathrm{CD}_{2} \mathrm{Cl}_{2}, 203 \mathrm{~K}, 121.5 \mathrm{MHz}\right):-$ 25.50. ESI-MS: $665.1\left(\left[\mathrm{Cu}_{2}(\mathrm{dppa})_{2}(\mathrm{dmp})_{2}\right]^{2+}\right.$, Calcd for $\mathrm{C}_{80} \mathrm{H}_{64} \mathrm{~N}_{4} \mathrm{P}_{4} \mathrm{Cu}_{2}$ : 665.134). Anal. Calcd for $\mathrm{C}_{80} \mathrm{H}_{64} \mathrm{~N}_{4} \mathrm{P}_{4} \mathrm{Cu}_{2} \mathrm{~B}_{2} \mathrm{~F}_{8} .\left(\mathrm{CH}_{2} \mathrm{Cl}_{2}\right)_{0.75}$ : C, 61.79; $\mathrm{H}, 4.21 ; \mathrm{N}, 3.57$. Found: C, 61.71; H, 3.70; N, 3.63 .

[Cu $\left.\mathrm{Cu}_{2}(\mu \text {-dppa })_{2}(\mathrm{Bphen})_{2}\right]\left(\mathrm{BF}_{4}\right)_{2}$. Isolated in $94 \%$ yield $(211 \mathrm{mg}, 0.120$ mmol) as yellow crystals. ${ }^{1} \mathrm{H}-\mathrm{NMR}\left(\mathrm{CD}_{2} \mathrm{Cl}_{2}, 400 \mathrm{MHz}, 293 \mathrm{~K}\right): 8.65(\mathrm{~d}, \mathrm{~J}=$ $5 \mathrm{~Hz}, 4 \mathrm{H}), 8.07(\mathrm{~s}, 4 \mathrm{H}), 7.68(\mathrm{~m}, 12 \mathrm{H}), 7.63(\mathrm{~d}, J=5 \mathrm{~Hz}, 4 \mathrm{H}), 7.59(\mathrm{~m}$, $12 \mathrm{H}), 7.21(\mathrm{~m}, 16 \mathrm{H}), 7.47(\mathrm{~m}, 8 \mathrm{H}), 7.41(\mathrm{~m}, 16 \mathrm{H}), 7.28(\mathrm{~m}, 16 \mathrm{H})$. ${ }^{31} \mathrm{P}\left\{{ }^{1} \mathrm{H}\right\}-N M R \quad\left(\mathrm{CD}_{2} \mathrm{Cl}_{2}, \quad 293 \mathrm{~K}, \quad 121.5 \mathrm{MHz}\right):-23.26$. ESI-MS: 789.2 $\left(\left[\mathrm{Cu}_{2}(\mathrm{dppa})_{2}(\mathrm{Bdmp})_{2}\right]^{2+}\right.$, Calcd for $\mathrm{C}_{100} \mathrm{H}_{72} \mathrm{~N}_{4} \mathrm{P}_{4} \mathrm{Cu}_{2}:$ 789.16). Anal. Calcd for $\mathrm{C}_{100} \mathrm{H}_{72} \mathrm{~N}_{4} \mathrm{P}_{4} \mathrm{Cu}_{2} \mathrm{~B}_{2} \mathrm{~F}_{8}: \mathrm{C}, 68.47 ; \mathrm{H}, 4.14 ; \mathrm{N}, 3.19$. Found: $\mathrm{C}, 68.21$; $\mathrm{H}, 4.19 ; \mathrm{N}, 3.02$.

[Cu $\left.\mathrm{Cu}_{2}(\mu \text {-dppa })_{2}(\mathrm{Bdmp})_{2}\right]\left(\mathrm{BF}_{4}\right)_{2}$. Isolated in $88 \%$ yield $(202 \mathrm{mg}, 0.112$ $\mathrm{mmol})$ as bronze crystals. ${ }^{1} \mathrm{H}-\mathrm{NMR}\left(\mathrm{CD}_{2} \mathrm{Cl}_{2}, 400 \mathrm{MHz}, 293 \mathrm{~K}\right): 8.08(\mathrm{~s}, 4 \mathrm{H})$ $7.65 \mathrm{~m}, 50 \mathrm{H}), 7.55(\mathrm{~s}, 4 \mathrm{H}), 7.49(\mathrm{~m}, 8 \mathrm{H}), 7.40(\mathrm{~m}, 16 \mathrm{H}), 7.26(\mathrm{~m}, 16 \mathrm{H})$, 2.26 (s, $12 \mathrm{H}) .{ }^{31} \mathrm{P}\left\{{ }^{1} \mathrm{H}\right\}-\mathrm{NMR}\left(\mathrm{CD}_{2} \mathrm{Cl}_{2}, 293 \mathrm{~K}, 121.5 \mathrm{MHz}\right):-24.61$. ESI-MS: $817.2\left(\left[\mathrm{Cu}_{2}(\mathrm{dppa})_{2}(\mathrm{Bdmp})_{2}\right]^{2+}\right.$, Calcd for $\left.\mathrm{C}_{104} \mathrm{H}_{80} \mathrm{~N}_{4} \mathrm{P}_{4} \mathrm{Cu}_{2}: 817.19\right)$. Anal. Calcd for $\mathrm{C}_{104} \mathrm{H}_{80} \mathrm{~N}_{4} \mathrm{P}_{4} \mathrm{Cu}_{2} \mathrm{~B}_{2} \mathrm{~F}_{8}: \mathrm{C}, 69.00 ; \mathrm{H}, 4.45 ; \mathrm{N}, 3.09$. Found: C, $68.91 ; \mathrm{H}, 4.56 ; \mathrm{N}, 3.01$.

$\left[\mathrm{Cu}_{2}(\mu \text {-dppa })_{2}(\mathrm{mpp})_{2}\right]\left(\mathrm{BF}_{4}\right)_{2}$. Isolated in $92 \%$ yield $(187 \mathrm{mg}, 0,117 \mathrm{mmol})$ as bronze crystals. ${ }^{1} \mathrm{H}-\mathrm{NMR}\left(\mathrm{CDCl}_{2} \mathrm{CDCl}_{2}, 400 \mathrm{MHz}, 343 \mathrm{~K}\right): 8.66(\mathrm{~d}, J=$ $8 \mathrm{~Hz}, 2 \mathrm{H}), 8.59$ (dd, $J=8$ and $1 \mathrm{~Hz}, 2 \mathrm{H}), 8.39(\mathrm{dd}, J=4$ and $1 \mathrm{~Hz}, 4 \mathrm{H})$, $8.11(\mathrm{AB}, J=9 \mathrm{~Hz}, 4 \mathrm{H}), 8.07(\mathrm{~d}, J=8 \mathrm{~Hz}, 2 \mathrm{H}), 7.75(\mathrm{~m}, 4 \mathrm{H}), 7.49(\mathrm{~m}, 8 \mathrm{H})$, $7.30(\mathrm{~m}, 4 \mathrm{H}), 7.20(\mathrm{~m}, 8 \mathrm{H}), 7.10(10 \mathrm{H}) .{ }^{31} \mathrm{P}\left\{{ }^{1} \mathrm{H}\right\}-\mathrm{NMR}\left(\mathrm{CD}_{2} \mathrm{Cl}_{2}, 203 \mathrm{~K}\right.$, 121.5 MHz): -22.69. ESI-MS: $713.3\left(\left[\mathrm{Cu}_{2}(\mathrm{dppa})_{2}(\mathrm{mpp})_{2}\right]^{2+}\right.$, Calcd for $\mathrm{C}_{88} \mathrm{H}_{64} \mathrm{~N}_{4} \mathrm{P}_{4} \mathrm{Cu}_{2}:$ 713.13). Anal. Calcd for $\mathrm{C}_{88} \mathrm{H}_{64} \mathrm{~N}_{4} \mathrm{P}_{4} \mathrm{Cu}_{2} \mathrm{~B}_{2} \mathrm{~F}_{8} \cdot \mathrm{CH}_{2} \mathrm{Cl}_{2}$ : C, 63.36; H, 3.94; N, 3.32. Found: C, 63.58; H, 3.96; N, 3.40 .

\section{X-ray crystal structures}

$\left[\mathrm{Cu}_{2}(\mu \text {-dppa })_{2}(\text { phen })_{2}\right]\left(\mathrm{BF}_{4}\right)_{2}$. $\left(\mathrm{CH}_{2} \mathrm{Cl}_{2}\right)_{2}$. Crystals suitable for $\mathrm{X}$-ray crystalstructure analysis were obtained by slow diffusion of $\mathrm{Et}_{2} \mathrm{O}$ into a $\mathrm{CH}_{2} \mathrm{Cl}_{2}$ solution of $\left[\mathrm{Cu}_{2}(\mu \text {-dppa })_{2}(\text { phen })_{2}\right]\left(\mathrm{BF}_{4}\right)_{2}$. Data were collected at $173 \mathrm{~K}$ on a Bruker Appex-II CCD diffractometer (Mo-K $\alpha$ radiation, $\lambda=0.71073 \AA$ ). The 
structure was solved by direct methods (SHELXS-97) and refined against $F^{2}$ using the SHELXL-97 software. The non-hydrogen atoms were refined anisotropically, using weighted full-matrix least-squares on $\mathrm{F}^{2}$. The $\mathrm{H}$ atoms were included in calculated positions and treated as riding atoms using SHELXL default parameters. The crystallographic data are reported in Table S1.

$\left.\mathrm{Cu}_{2}(\mu \text {-dppa })_{2}(\mathrm{dmp})_{2}\right]\left(\mathrm{BF}_{4}\right)_{2}$. $\left(\mathrm{CH}_{2} \mathrm{Cl}_{2}\right)_{2}$. Crystals suitable for $\mathrm{X}$-ray crystalstructure analysis were obtained by slow diffusion of $\mathrm{Et}_{2} \mathrm{O}$ into a $\mathrm{CH}_{2} \mathrm{Cl}_{2}$ solution of $\left[\mathrm{Cu}_{2}(\mu-\mathrm{dppa})_{2}(\mathrm{dmp})_{2}\right]\left(\mathrm{BF}_{4}\right)_{2}$. Data were collected at $173 \mathrm{~K}$ on a Bruker Appex-II CCD diffractometer (Mo-K $\alpha$ radiation, $\lambda=0.71073 \AA$ ). The structure was solved by direct methods (SHELXS-97) and refined against $F^{2}$ using the SHELXL-97 software. The non-hydrogen atoms were refined anisotropically, using weighted full-matrix least-squares on $\mathrm{F}^{2}$. The $\mathrm{H}$ atoms were included in calculated positions and treated as riding atoms using SHELXL default parameters. The crystallographic data are reported in Table S1.

$\left[\mathrm{Cu}_{2}(\mu-\mathrm{dppa})_{2}(\mathrm{Bphen})_{2}\right]\left(\mathrm{BF}_{4}\right)_{2} \cdot\left(\mathrm{C}_{6} \mathrm{H}_{6}\right)$. Crystals suitable for X-ray crystalstructure analysis were obtained by slow diffusion of $\mathrm{C}_{6} \mathrm{H}_{6}$ into a $\mathrm{CHCl}_{3}$ solution of $\left[\mathrm{Cu}_{2}(\mu \text {-dppa })_{2}(\mathrm{Bphen})_{2}\right]\left(\mathrm{BF}_{4}\right)_{2}$. Data were collected at $173 \mathrm{~K}$ on a Bruker Appex-II CCD diffractometer (Mo-K $\alpha$ radiation, $\lambda=0.71073 \AA$ ). The structure was solved by direct methods (SHELXS-97) and refined against $F^{2}$ using the SHELXL-97 software. The non-hydrogen atoms were refined anisotropically, using weighted full-matrix least-squares on $\mathrm{F}^{2}$. The $\mathrm{H}$-atoms were included in calculated positions and treated as riding atoms using SHELXL default parameters. The crystallographic data are reported in Table S1.

$\left[\mathrm{Cu}_{2}(\mu-\mathrm{dppa})_{2}(\mathrm{mpp})_{2}\right]\left(\mathrm{BF}_{4}\right)_{2}$. $\left(\mathrm{CH}_{2} \mathrm{Cl}_{2}\right)_{2}$. Crystals suitable for X-ray crystalstructure analysis were obtained by slow diffusion of $\mathrm{Et}_{2} \mathrm{O}$ into a $\mathrm{CH}_{2} \mathrm{Cl}_{2}$ solution of $\left[\mathrm{Cu}_{2}(\mu-\mathrm{dppa})_{2}(\mathrm{mpp})_{2}\right]\left(\mathrm{BF}_{4}\right)_{2}$. Data were collected at $173 \mathrm{~K}$ on a Bruker Appex-II CCD diffractometer (Mo-K $\alpha$ radiation, $\lambda=0.71073 \AA$ ). The structure was solved by direct methods (SHELXS-97) and refined against $F^{2}$ using the SHELXL-97 software. The non-hydrogen atoms were refined anisotropically, using weighted full-matrix least-squares on $\mathrm{F}^{2}$. The $\mathrm{H}$ atoms were included in calculated positions and treated as riding atoms using SHELXL default parameters. The crystallographic data are reported in Table S1.

The X-ray crystal structures have been deposited at the Cambridge Structural Database (CCDC deposition numbers: 1897419, 1897422, 1897425 and 1897440).

Electrochemistry. The electrochemical properties of compounds $\left[\mathrm{Cu}_{2}(\mu-\right.$ dppa $\left.)_{2}(\text { phen })_{2}\right]\left(\mathrm{BF}_{4}\right)_{2}, \quad\left[\mathrm{Cu}_{2}(\mu-\mathrm{dppa})_{2}(\mathrm{dmp})_{2}\right]\left(\mathrm{BF}_{4}\right)_{2}, \quad\left[\mathrm{Cu}_{2}(\mu-\right.$ dppa $\left.)_{2}(\mathrm{Bphen})_{2}\right]\left(\mathrm{BF}_{4}\right)_{2}, \quad\left[\mathrm{Cu}_{2}(\mu-\mathrm{dppa})_{2}(\mathrm{Bdmp})_{2}\right]\left(\mathrm{BF}_{4}\right)_{2}$ and $\left[\mathrm{Cu}_{2}(\mu-\right.$

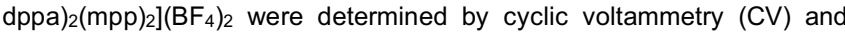
Osteryoung Square Wave Voltammetry (OSWV). The cyclic voltammetric measurements were carried out with a potentiostat Autolab PGSTAT100. Experiments were performed at room temperature in a homemade airtight three-electrode cell connected to a vacuum/argon line. The reference electrode consisted of a saturated calomel electrode (SCE) separated from the solution by a bridge compartment. The counter electrode was a platinum wire of ca. $1 \mathrm{~cm}^{2}$ apparent surface. The working electrode was a Pt microdisk (0.5 mm diameter). The supporting electrolyte $\left[\mathrm{nBu}_{4} \mathrm{~N}\right]\left[\mathrm{BF}_{4}\right]$ (Fluka, 99\% electrochemical grade) was used as received and simply degassed under argon. Dichloromethane was freshly distilled over $\mathrm{CaH}_{2}$ prior to use. The solutions used during the electrochemical studies were typically $1 \times 10^{-3} \mathrm{M}$ in compound and $0.1 \mathrm{M}$ in supporting electrolyte. Before each measurement, the solutions were degassed by bubbling $A r$ and the working electrode was polished with a polishing machine (Presi $\mathrm{P} 230)$. Under these experimental conditions, $\mathrm{Fc}^{+} / \mathrm{Fc}$ is observed at +0.55 $\pm 0.01 \mathrm{~V}$ vs. SCE. OSWVs were obtained using an amplitude of $20 \mathrm{mV}$, a frequency of $20 \mathrm{~Hz}$, and a step potential of $5 \mathrm{mV}$.

Photophysical measurements. Spectrofluorimetric-grade $\mathrm{CH}_{2} \mathrm{Cl}_{2}$ was used as solvent for spectroscopic investigations. The absorption spectra were recorded with a PerkinEImer Lambda 950 spectrophotometer.

For the photoluminescence experiments, the samples were placed in fluorimetric Suprasil quartz cuvettes $(1 \mathrm{~cm})$ and deaerated by bubbling argon for $15 \mathrm{~min}$. Solid state measurements were carried out on powders, as obtained after the crystallization, placed in quartz tubes. The uncorrected emission spectra were obtained with an Edinburgh Instruments FLS920 spectrometer equipped with a Peltier-cooled Hamamatsu R928 photomultiplier tube (PMT), having a spectral window of $185-850 \mathrm{~nm}$. An Osram XBO Xenon arc lamp $(450 \mathrm{~W})$ was used as the excitation light source. The corrected spectra were obtained via a calibration curve, determined using an Ocean Optics deuterium-halogen calibrated lamp (DH-3plus-CAL- EXT). Solid-state PLQY values were calculated by corrected emission spectra obtained from an Edinburgh FLS920 spectrometer equipped with a barium sulfate-coated integrating sphere (diameter of $3 \mathrm{in}$.) following the procedure described by Würth et al. ${ }^{[19]}$

The emission lifetimes $(\tau)$ of solid samples in the sub-microsecond time range were measured through the time-correlated single-photon counting (TCSPC) technique using a HORIBA Jobin Yvon IBH FluoroHub controlling a spectrometer equipped with a pulsed NanoLED ( $\lambda_{\text {exc }}=373$ $\mathrm{nm} ; 200 \mathrm{ps}$ time resolution after reconvolution) as the excitation source and a red-sensitive Hamamatsu R-3237-01 PMT as the detector (spectral window: $185-850 \mathrm{~nm}$ ). The analysis of the luminescence decay profiles, taken on the emission maximum, was accomplished with the DAS6 decay analysis software provided by the manufacturer, and the quality of the fit was assessed with the $x^{2}$ value close to unity and with the residuals randomly scattered along the time axis.

Experimental uncertainties are estimated to be $\pm 8 \%$ for $\tau$ determinations $\pm 20 \%$ for PLQY, and $\pm 2 \mathrm{~nm}$ and $\pm 5 \mathrm{~nm}$ for absorption and emission peaks respectively.

\section{Acknowledgments}

Financial support from the International Center for Frontier Research in Chemistry, the LabEx "Chimie des Systèmes Complexes" and CNR (PHEEL) is gratefully acknowledged. We thank M. Schmitt and E. Wasielewski for high field NMR measurements, L. Karmazin and C. Bailly for the X-ray crystal structure resolution and J.-M. Strub for the mass spectra.

Keywords: Copper • Dinuclear complex • Phenanthroline • Phosphine $\cdot$ Emission

[1] M. Wallesch, D. Volz, D. M. Zink, U. Schepers, M. Nieger, T. Baumann, S. Bräse, Chem. Eur. J. 2014, 20, 6578-6590.

[2] a) B. Bozic-Weber, E. C. Constable, C. E.; Housecroft, Coord. Chem Rev. 2013, 257, 3089-3106; b) C. E. Housecroft, E. C. Constable, Chem. Soc. Rev. 2015, 44, 8386-8398.

[3] a) O. Reiser, Acc. Chem. Res. 2016, 49, 1990-1996; b) A. C. HernandezPerez, S. K. Collins, Acc. Chem. Res. 2016, 49, 1557-1565; c) Y. Zhang, 
M. Schulz, M. Wächltler, M. Karnahl, B. Dietzek, Coord. Chem. Rev. 2018, 356, 127-146.

[4] M. Holler, B. Delavaux-Nicot, J.-F. Nierengarten, Chem. Eur. J. 2019 DOI: $10.1002 /$ chem.201805671

[5] For selected examples, see: a) D. G. Cuttell, S.-M. Kuang, P. E. Fanwick, D. R. McMillin, R. A. Walton, J. Am. Chem. Soc. 2002, 124, 6-7; b) S.-M Kuang, D. G. Cuttell, D. R. McMillin, P. E. Fanwick, R. A. Walton, Inorg. Chem. 2002, 41, 3313-3322; c) Q. Zhang, Q. Zhou, Y. Cheng, L. Wang, D. Ma, X. Jing, F. Wang, Adv. Funct. Mater. 2006, 16, 1203-1208; d) R. D. Costa, D. Tordera, E. Orti, H. Bolink, J. Schönle, S. Graber, C. E. Housecroft, E. C. Constable, J. A. Zampese, J. Mater. Chem. 2011, 21 16108-16118; e) R. Czerwieniec, J. Yu, H. Yersin, Inorg. Chem. 2011 50, 8293; f) S.-P. Luo, E. Mejía, A. Friedrich, A. Pazidis, H. Junge, A.-E. Surkus, R. Jackstell, S. Denurra, S. Gladiali, S. Lochbrunner, M. Beller, Angew. Chem. Int. Ed. 2013, 52, 419-423; g) S. Keller, E. C. Constable, C. E. Housecroft, M. Neuburger, A. Prescimone, G. Longo, A. Pertegás, M. Sessolo, H. J. Bolink, Dalton Trans. 2014, 43, 16593-16596; h) B. Wang, D. P. Shelar, X. Z. Han, T. T. Li, X. Guan, W. Lu, K. Liu, Y. Chen, W.-F. Fu, C.-M. Che, Chem. Eur. J. 2015, 21, 1184-1190; i) A. J. J Lennox, S. Fischer, M. Jurrat, S.-P. Luo, N. Rockstroh, H. Junge, R. Ludwig, M. Beller, Chem. Eur. J. 2016, 22, 1233-1238; j) S. Keller, A Pertegás, G. Longo, L. Martínez, J. Cerdá, J. M. Junquera-Hernández, A. Prescimone, E. C. Constable, C. E. Housecroft, E. Ortí, H. J. Bolink J. Mater. Chem. C 2016, 4, 3857-3871; k) F. Brunner, L. Martínez-Sarti, S. Keller, A. Pertegás, A. Prescimone, E. C. Constable, H. J. Bolink, C E. Housecroft, Dalton Trans. 2016, 45, 15180-15192 I) M. Heberle, S. Tschierlei, N. Rockstroh, M. Ringenberg, W. Frey, H. Junge, M. Beller, S. Lochbrunner, M. Karnahl, Chem. Eur. J. 2017, 23, 312-319; m) S. Keller, F. Brunner, J. M. Junquera-Hernández, A. Pertegás, M. G. La Placa, A. Prescimone, E. C. Constable, H. J. Bolink, E. Ortí, C. E. Housecroft, ChemPlusChem 2018, 83, 217-219; n) B. Z. Xu, Y. Cao, B O. Patrick, M. O. Wolf, Chem. Eur. J. 2018, 24, 10315-10319; o) D. Moonshiram, P. Garrido-Barros, C. Gimbert-Suriñach, A. Picón, C. Liu, X. Zhang, M. Karnahl, A. Llobet, Chem. Eur. J. 2018, 24, 6464-6472.

[6] a) N. Armaroli, G. Accorsi, M. Holler, O.; Moudam, J.-F. Nierengarten, Z. Zhou, R. T. Wegh, R. Welter, Adv. Mater. 2006, 18, 1313-1316; b) N Armaroli, G. Accorsi, G. Bergamini, P. Ceroni, M. Holler, O. Moudam, C. Duhayon, B. Delavaux-Nicot, J.-F. Nierengarten, Inorg. Chim. Acta 2007, 360, 1032-1042; c) A. Listorti, G. Accorsi, Y. Rio, N. Armaroli, O Moudam, A. Gégout, B. Delavaux-Nicot, M. Holler, J.-F. Nierengarten, Inorg. Chem 2008, 47, 6254-6261; d) M. Mohankumar, M. Holler, J.-F. Nierengarten, J.-P. Sauvage, Chem. Eur. J. 2012, 18, 12192-12195; e)
M. Mohankumar, M. Holler, M. Schmitt, J.-P. Sauvage, J.-F. Nierengarten, Chem. Commun. 2013, 49, 1261-1263.

[7] A. Kaeser, M. Mohankumar, J. Mohanraj, F. Monti, M. Holler, J. J. Cid, O. Moudam, I. Nierengarten, L. Karmazin-Brelot, C. Duhayon, B. Delavaux-Nicot, N. Armaroli, J.-F. Nierengarten, Inorg. Chem. 2013, 52, 12140-12151

[8] a) K. Saito, T. Arai, N. Takahashi, T. Tsukuda, T. Tsubomura, Dalton Trans. 2006, 4444-4448; b) C. Femoni, S. Muzzioli, A. Palazzi, S. Stagni, S. Zacchini, F. Monti, G. Accorsi, M. Bolognesi, N. Armaroli, M. Massi, G. Valenti, M. Marcaccio, Dalton Trans. 2013, 42, 997-1010; c) X.-L. Li, M. Chen, Y.-b. Ai, F.-L. Yang, X.-L. Li, F. Li, Inorg. Chem. 2014, 53, 29222931; d) T. Tsabomura, K. Kimura, M. Nishikawa, T. Tsukuda, Dalton Trans. 2015, 44, 7554-7562

[9] E. Leoni, J. Mohanraj, M. Holler, M. Mohankumar, I. Nierengarten, F. Monti, A. Sournia-Saquet, B. Delavaux-Nicot, J.-F. Nierengarten, N. Armaroli, Inorg. Chem. 2018, 57, 15537-15549.

[10] a) A. Fazal, A. Al-Dawsari, B. El Ali, L. Ouahab, M. Fettouhi, J. Coord. Chem. 2014, 67, 2357-2364; b) A. Fazal, B. El Ali, L. Ouahab, M. Fettouhi, Polyhedron 2013, 49, 7-11.

[11] Y.-C. Liu, C.-I. Li, W.-Y. Yeh, G.-H. Lee, S.-M Peng, Inorg. Chim. Acta 2006, 359, 2361-2368

[12] B. R. James, R. J. P. Williams, J. Chem. Soc. 1961, 2007-2019.

[13] M. Mohankumar, F. Monti, M. Holler, F. Niess, B. Delavaux-Nicot, N. Armaroli, J.-P. Sauvage, J.-F. Nierengarten, Chem. Eur. J. 2014, 20 , 12083-12090.

[14] M. Mohankumar, M. Holler, E. Meichsner, J.-F. Nierengarten, F. Niess J.-P. Sauvage, B. Delavaux-Nicot, E. Leoni, F. Monti, J. M. Malicka, M. Cocchi, E. Bandini, N. Armaroli, J. Am. Chem. Soc. 2018, 140, 23362347

[15] Y. Ruina, W. Dongmei, L. Yingfan, J. Douman, Russ. J. Inorg. Chem. 2001, 46, 993-998.

[16] N. Armaroli, L. De Cola, V. Balzani, J.-P. Sauvage, C. O. DietrichBuchecker, J.-M. Kern, J. Chem. Soc., Faraday Trans. 1992, 88, 553556.

[17] G. Accorsi, A. Listorti, K. Yoosaf, N. Armaroli, Chem. Soc. Rev. 2009, 38 1690-1700

[18] K. Kubiček, S. Thekku Veedu, D. Storozhuk, R. Kia, S. Techert, Polyhedron 2017, 124, 166-176.

[19] C. Wurth, M. Grabolle, J. Pauli, M. Spieles, U. Resch-Genger, Nat. Protoc. 2013, 8, 1535-1550. 


\section{FULL PAPER}

The presence of a phenyl substituent on the phenanthroline (NN) ligand of $\left[\mathrm{Cu}_{2}(\mu \text {-dppa })_{2}(\mathrm{NN})_{2}\right]\left(\mathrm{BF}_{4}\right)_{2}$ derivatives (dppa:

bis(diphenylphosphino)acetylene) contributes to rigidify the dimetallacycle and therefore to significantly increase its emission quantum yield.

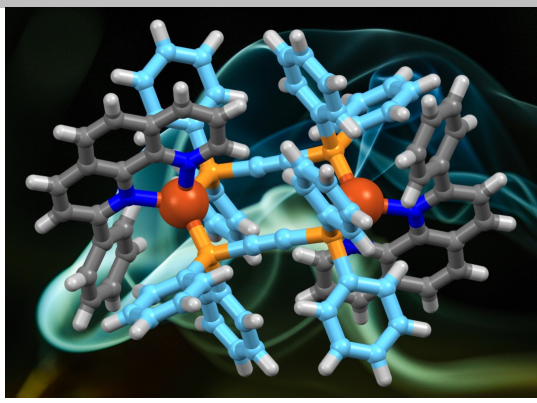

\section{Copper}

Jean-François Nierengarten, ${ }^{*[a]}$ Iwona Nierengarten, ${ }^{[a]}$ Michel Holler, ${ }^{[a]}$ Alix Sournia-Saquet, ${ }^{[b]}$ Béatrice DelavauxNicot, ${ }^{*[b]}$ Enrico Leoni, ${ }^{[c]}$ Filippo Monti, ${ }^{[d]}$ Nicola Armaroli*[d]

Page No. - Page No.

Dinuclear Copper(I) Complexes

Combining

Bis(diphenylphosphino)acetylene with 1,10-Phenanthroline Ligands 